\title{
KONSEP PENGEMBANGAN EKOWISATA GARAM MELALUI PENDEKATAN TRIPLE HELIX DI PULAU MADURA
}

\author{
Triana Setiyarini dan Yustina Chrismardani \\ Jurusan Manajemen, Fakultas Ekonomi Dan Bisnis \\ Universitas Trunojoyo Madura
}

\begin{abstract}
Madura Island has long been known as a salt island. Although there are many tourist destinations in Madura, no one has utilized and developed salt as an ecotourism potential. Through salt ecotourism, it is expected to be a solution to some of the problems associated with salt, especially to improve the welfare of salt farmers. The purpose of this study was to determine the concept of salt ecotourism development through the triple helix approach on Madura Island. This type of research is inductive analysis by collecting, compiling and describing various actual data, documents and information. The data that has been obtained is then analyzed by descriptive analysis method. The results showed that the potential for salt cultivation in four districts in Madura namely Bangkalan, Sampang, Pamekasan and Sumenep can be used as an opportunity to develop attractive tourism through the concept of salt ecotourism. This is because Madura's land could meet five basic principles of ecotourism development in Indonesia, namely the principles of conservation, education, tourism, economy, and participation of local communities. Salt ecotourism requires collaboration from academics, businesses represented by groups of salt farmers, and the government. These three actors, called triple helix, have different roles in order to develop salt ecotourism starting from planning, utilization and control.

Keywords: salt ecotourism, triple helix, ecotourism development
\end{abstract}

\section{PENDAHULUAN}

Pariwisata adalah industri yang terus tumbuh di seluruh dunia dengan banyak negara sekarang bergantung pada industri pariwisata di negara mereka untuk terus tumbuh dan berkembang. Pada tahun 2006 ada 234 juta pekerjaan di industri, yang merupakan $8,2 \%$ dari total pekerjaan di seluruh dunia (World Tourism Analysis, 2007). Sektor pariwisata Indonesia diproyeksikan mampu menyumbang produk domestik bruto sebesar 15 persen. Lebih jauh, sektor 
pariwisata diyakini mampu memutus rantai kemiskinan, pengangguran, juga kesenjangan dengan cepat dan tepat (Liputan6.com, 2018). Di pulau Madura terdapat 42 tempat wisata. Diantaranya Wisata Bukit Jaddih di Kabupaten Bangkalan; Air Terjun Toroan yang berada di Kabupaten Sampang; Bukit Cinta yang berlokasi di Kabupaten Pamekasan; dan Wisata Gili Labak yang lokasinya berada di Kabupaten Sumenep.

Ada sejumlah tantangan yang dihadapi oleh Indonesia untuk mengembangkan pariwisata. Salah satunya adalah pengembangan destinasi Indonesia dikritik dalam hal enviromental sustainability. Indonesia dianggap tidak peduli dengan kelestarian alam (Kompas.com, 2017). Pertanyaannya sekarang untuk industri adalah bagaimana meminimalkan dampak para pelancong ini. Sejak tahun 1980 satu solusi telah ditawarkan: ekowisata. Dengan janji-janjinya untuk tidak hanya melestarikan lingkungan tetapi juga menawarkan peluang yang unik baik secara budaya maupun alam, ini telah menjadi jalan bagi banyak industri untuk melihat ke depan bagi masa depan pariwisata. Australian Department of Tourism (Black, 1999) mendefinisikan ekowisata adalah wisata berbasis pada alam dengan mengikutkan aspek pendidikan dan interpretasi terhadap lingkungan alami dan budaya masyarakat dengan pengelolaan kelestarian ekologis.

Berbagai terobosan destinasi ekowisata baru memang patut dirintis. Jika selama ini sudah dikenal ekowisata pedesaan seperti Ekowisata Subak Sembung yang berlokasi di Kotamadya Denpasar, Provinsi Bali atau seperti di Kabupaten Malang yang memiliki Ekowisata Kebun Kopi Amadanom, Dampit, mengapa tidak dengan ekowisata garam yang tak kalah menarik untuk dijelajahi di sentrasentra pembuatannya. Pada tahun 2012 telah dideklarasikan Pulau Madura sebagai Pulau Garam. Deklarasi ini mengandung makna adanya perhatian khusus kepada pulau Madura baik secara potensi maupun sumber mata pencaharian sebagian besar penduduk pulau Madura dalam berproduksi garam. (pusriskel.litbang.kkp.go.id, 2013). Jika anda melewati kabupaten Sumenep, dengan mudahnya menemukan tambak garam yang dari kejauhan seperti hamparan salju mengeras. Pemandangan itu juga diperindah dengan putaran rodaroda kincir angin. 
Dalam konsep ekowisata terdapat unsur konservasi atau pelestarian. Potensi ekowisata garam di Madura akan sulit dikembangkan jika terjadi penyusutan luas tambak garam karena beberapa permasalahan yang dialami para petani garam, diantaranya yaitu stigma dikalangan masyarakat masih banyak menganggap bahwa garam bukanlah potensi usaha yang menguntungkan. Dinas Kelautan dan Perikanan Kabupaten Sampang, Jawa Timur, menyebutkan, lahan tambak garam terus menyusut akibat beralih fungsi untuk perumahan. Saat ini luas lahan tambak garam produktif masyarakat dan perusahaan hanya sekitar 2.800 hektare. Setiap tahun terjadi penyusutan lahan tambak garam 1 persen dari total luas lahan garam produktif di wilayah itu (Antaranews Jatim, 2018). Salah satu usaha untuk melestarikan budidaya garam adalah melalui teknologi. Selaku akademisi, Universitas Trunojoyo Madura mencarikan solusi agar saat kemarau basah kembali datang garam tetap bisa diproduksi. Maka dibuatlah rumah garam yang terletak di Kecamatan Pademawu, Kabupaten Pamekasan, Jawa Timur, yang sejak awal memang dibuat khusus untuk kepentingan riset dan inovasi. Pemerintah harus berperan aktif misalnya dengan mengajak petani melihat rumah garam percontohan supaya mereka tertarik (tempo.co, 2017).

Meskipun Madura telah menjadi salah satu penghasil garam utama, tidak otomatis berimbas pada kesejahteraan para petani garam. Kebijakan impor garam yang dikeluarkan pemerintah menuai ancaman dari petani garam rakyat di Madura, karena jelas-jelas semakin memperburuk hasil produksi petani garam di Madura yang dari sejak dulu sudah terombang ambingkan oleh kebijakan pemerintah yang dalihnya demi kepentingan rakyat, tetapi justru semakin memojokkan kehidupan mereka, hingga banyak diantara petani garam yang mati pencahariannya (tribunnews.com, 2018). Salah satu solusi yang dapat ditawarkan untuk mengatasi permasalahan ekonomi yang dihadapi petani garam Madura adalah melalui usaha ekowisata garam. Dengan adanya pola ekowisata berbasis masyarakat dibutuhkan intervensi dan kolaborasi beberapa pihak untuk mendorong pengembangan ekowisata garam, yaitu pihak akademisi, pelaku bisnis, dan pemerintah yang disebut sebagai Triple Helix.

Potensi ekowisata garam di Madura selama ini belum mendapat perhatian 
serius dari masyarakat dan instansi terkait. Masih banyak masyarakat baik di Madura sendiri maupun masyarakat luas yang belum mengetahui bagaimana proses produksi garam. Hal ini dapat dijadikan peluang untuk mengembangkan ekowisata garam melalui peran dari akademisi, bisnis dan pemerintah. Apalagi akses menuju pulau Madura semakin dekat, karena ada Jembatan Suramadu yang menghubungkan langsung dengan Surabaya sehingga bisa ditempuh dalam waktu cepat. Terkait hal tersebut maka perlu adanya pengkajian secara mendalam mengenai potensi ekowisata di pulau Madura. Hal ini penting guna merencanakan konsep pengembangan ekowisata garam secara berkelanjutan.

\section{LANDASAN TEORI}

\section{A. Pengertian Ekowisata}

Australian Department of Tourism (Black, 1999) mendefinisikan ekowisata adalah wisata berbasis pada alam dengan mengikutkan aspek pendidikan dan interpretasi terhadap lingkungan alami dan budaya masyarakat dengan pengelolaan kelestarian ekologis. Sedangkan menurut Departemen Kebudayaan dan Pariwisata Republik Indonesia, Ekowisata merupakan konsep pengembangan pariwisata yang berkelanjutan yang bertujuan untuk mendukung upaya-upaya pelestarian lingkungan (alam dan budaya) dan meningkatkan partisipasi masyarakat dalam pengelolaan, sehingga memberikan manfaat ekonomi kepada masyarakat dan pemerintah setempat.

\section{B. Pengembangan Ekowisata}

Prinsip utama ekowisata yang ditawarkan oleh Choy (Sastrayuda, 2010) yaitu: 1) Lingkungan ekowisata harus bertumpu pada lingkungan alam dan budaya yang relatif belum tercemar atau terganggu; 2) Masyarakat ekowisata harus dapat memberikan manfaat ekologi, sosial, dan ekonomi langsung kepada masyarakat setempat; 3) Pendidikan dan pengalaman ekowisata harus dapat meningkatkan pemahaman akan lingkungan alam dan budaya yang terkait. 4) Keberlanjutan ekowisata harus dapat memberikan sumbangan positif bagi keberlanjutan ekologi dan lingkungan tempat kegiatan, tidak merusak, tidak 
menurunkan mutu, baik jangka pendek dan jangka panjang. 5) Manajemen ekowisata harus dapat dikelola dengan cara yang bersifat menjamin daya hidup jangka panjang bagi lingkungan alam dan budaya yang terkait di daerah tempat kegiatan ekowisata, sambil menerapkan cara mengelola yang terbaik untuk menjamin kelangsungan hidup ekonominya.

Menurut Permendagri No.33 Tahun 2009, pengembangan ekowisata adalah kegiatan perencanaan, pemanfaatan, dan pengendalian ekowisata. Perencanaan ekowisata merupakan bagian dari perencanaan pariwisata daerah. Perencanaan ekowisata yang dituangkan dalam Rencana Kerja Pemerintah Daerah RKPD) memuat antara lain: 1) jenis ekowisata; 2) data dan informasi; 3) potensi pangsa pasar; 4) hambatan; 5) lokasi; 6) luas; 7) batas; 8) kebutuhan biaya; 9) target waktu pelaksanaan; dan 10) disain teknis.

Pemanfaatan ekowisata mencakup: 1) pengelolaan kawasan ekowisata; 2) pemeliharaan kawasan ekowisata; 3) pengamanan kawasan ekowisata; dan 4) penggalian potensi kawasan ekowisata baru.

Pengendalian ekowisata dilakukan antara lain terhadap: 1) fungsi kawasan; 2) pemanfaatan ruang; 3) pembangunan sarana dan prasarana; 4) kesesuaian spesifikasi konstruksi dengan desain teknis; dan 5) kelestarian kawasan ekowisata. Pengendalian ekowisata dilakukan melalui: pemberian izin pengembangan ekowisata, pemantauan pengembangan ekowisata, penertiban atas penyalahgunaan izin pengembangan ekowisata, dan penanganan dan penyelesaian masalah atau konflik yang timbul dalam penyelenggaraan ekowisata.

\section{Ekowisata Berbasis Pemberdayaan Masyarakat}

Menurut Departemen Kebudayaan dan Pariwisata dan WWF-Indonesia (2009), pola ekowisata berbasis masyarakat adalah pola pengembangan ekowisata yang mendukung dan memungkinkan keterlibatan penuh oleh masyarakat setempat dalam perencanaan, pelaksanaan, dan pengelolaan usaha ekowisata dan segala keuntungan yang diperoleh. Ekowisata berbasis masyarakat dapat menciptakan kesempatan kerja bagi masyarakat setempat, dan mengurangi 
kemiskinan, di mana penghasilan ekowisata adalah dari jasa-jasa wisata untuk turis: fee pemandu; ongkos transportasi; homestay; menjual kerajinan, dll. Ekowisata membawa dampak positif terhadap pelestarian lingkungan dan budaya asli setempat yang pada akhirnya diharapkan akan mampu menumbuhkan jati diri dan rasa bangga antar penduduk setempat yang tumbuh akibat peningkatan kegiatan ekowisata.

\section{Pengembangan Ekowisata Melalui Pendekatan Triple Helix}

Model Triple Helix menunjukkan hubungan yang saling menguntungkan diantara tiga pemangku kepentingan (pemerintah, bisnis/industri dan universitas) sehingga dimungkinkan untuk mendorong inovasi (Page, 2009). Etzkowitz (2008) menambahkan bahwa interaksi antara pemangku kepentingan yang terlibat sangat penting untuk inovasi dalam masyarakat berbasis pengetahuan. Model Triple Helix memiliki dua level, salah satunya adalah interaksi antara para pemangku kepentingan, dan lainnya sebagai pertukaran peran (Gambar 1). Etzkowitz menjelaskan peran pemangku kepentingan, di mana universitas adalah "prinsip generatif masyarakat berbasis pengetahuan", industri adalah "lokus produksi", dan pemerintah "sumber hubungan kontraktual yang menjamin interaksi stabil dan pertukaran". Adapun pertukaran peran, contohnya adalah bahwa universitas dan pemerintah "bertindak sebagai pengusaha" yang menunjukkan bahwa itu tidak terbatas pada perusahaan.

\section{Gambar 1 The Triple Helix Interaction}

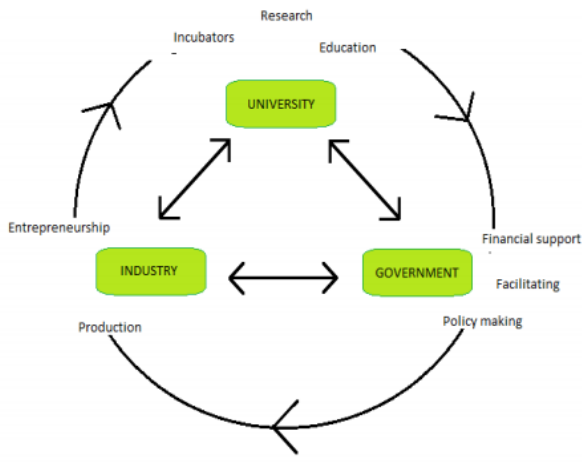

Sumber: Etzkowitz, 2008 
Menurut Permendagri No. 33 Tahun 2009, pemerintah daerah dalam mengembangkan ekowisata dilakukan melalui: a. perencanaan; b. pemanfaatan; dan c. pengendalian. Perencanaan, pemanfaatan dan pengendalian ekowisata dilakukan secara terpadu oleh pelaku ekowisata. Negara mengatur pihak-pihak yang terlibat dalam kegiatan ekowisata melalui Permendagri No. 33 Tahun 2009 sebagai berikut: Pelaku ekowisata adalah pemerintah, pemerintah daerah, dunia usaha, dan masyarakat yang bergerak di bidang wisata. Dari penjelasan tersebut maka jelaslah bahwa pengelolaan ekowisata melibatkan peran dari akademisi, bisnis dan pemerintah.

Hapsari dan Nurhajijah (2017) melakukan penelitian tentang peran triple helix dalam pengembangan ekowisata di Desa Cibuntu, Kuningan, Jawa Barat. Peran tiga pemangku kepentingan yang disinergikan, dikenal sebagai Triple Helix. Ketiganya memiliki peran tersendiri. Akademisi berperan dalam proses observasi dan studi terhadap potensi wisata desa Cibuntu, membuat roadmap pariwisata desa, sosialisasi kepada masyarakat, pembentukan KOMPEPAR (Kelompok Gerakan Pariwisata), pendampingan, dan pelatihan kepada masyarakat. Peran industri diwakili oleh komunitas desa Cibuntu. Mereka adalah aktor utama dalam mengendalikan desa wisata. Komunitas diminta menjadi pemandu wisata bagi wisatawan, dan keterbukaan terhadap wisatawan. Pemerintah bertindak sebagai katalisator, fasilitator, dan advokasi desa wisata Cibuntu, dan sebagai regulator yang menghasilkan kebijakan, dan sebagai perencana kota untuk mengembangkan desa wisata Cibuntu.

\section{METODE PENELITIAN}

Jenis penelitian ini bersifat analisis induktif yaitu dengan mengumpulkan, menyusun dan mendeskripsikan berbagai data, dokumen dan informasi yang aktual. Materi yang diperoleh akan di interpretasikan dalam bentuk pemaparan dan analisis sehingga tujuan dari penelitian ini dapat tercapai.

Penelitian ini diawali dengan melakukan kajian terhadap sejumlah literatur

yang dapat mendukung pendekatan analisis. Data-data yang sudah diperoleh kemudian dianalisis dengan metode analisis deskriptif. Metode analisis deskriptif 
dilakukan dengan cara mendeskripsikan fakta-fakta yang kemudian disusul dengan analisis, tidak semata-mata menguraikan, melainkan juga memberikan pemahaman dan penjelasan secukupnya.

\section{PEMBAHASAN}

\section{A. Potensi Ekowisata Garam Di Madura}

Madura merupakan penghasil garam utama dengan sentra garam berada di empat kabupaten yaitu Kabupaten Sampang, Pamekasan, Sumenep dan Bangkalan. Berdasarkan luas lahan, tambak garam di Madura mencapai 30 \% luas tambak garam nasional. Sentra garam lainnya terdapat di Provinsi Jawa Timur, NTT, Jawa Tengah , Jawa Barat, NTB dan Sulawesi Selatan. Sedangkan dilihat dari tingkat produksinya pada Tahun 2014, sumbangan Madura terhadap produksi nasional mencapai 600 ribu ton atau setara dengan 35\% dari produksi nasional (Efendy et al, 2015). Hasil produksi garam di Madura terbilang besar. Lahan pertanian garam rakyat di kawasan tersebut juga luas. Setidaknya hingga 2016, Madura memiliki lahan seluas lebih dari 11.695 hektare untuk pertanian garamnya. Lahan ini terbagi menjadi lahan untuk garam rakyat dan milik PT Garam.

Mengingat lahan pegaraman di Madura yang begitu luas, hal ini dapat menjadi potensi dan peluang usaha jasa pariwisata dengan konsep ekowisata. Dalam konsep ekowisata terdapat unsur konservasi. Hal ini sesuai dengan kondisi budidaya garam yang membutuhkan pelestarian agar tetap berkesinambungan antar generasi mengingat banyak kendala dalam pengelolaan usaha garam yang bisa menurunkan minat generasi mendatang untuk meneruskan usaha pegaraman. Ekowisata garam juga menawarkan wisata pemandangan yang unik terutama pada waktu panen garam seperti terlihat hamparan dan gundukan salju, ditambah dengan kincir angin yang eksotis akan menjadi pengalaman yang memorable dan foto yang instagramable. Ekowisata garam juga mengandung unsur edukasi karena banyak masyarakat yang belum mengetahui proses pembuatan garam. Potensi masing-masing wilayah kabupaten Madura adalah sebagai berikut: 
Kabupaten Bangkalan yang terletak di paling ujung barat pulau Madura, merupakan kabupaten penghasil garam terendah jika dibandingkan dengan 3 kabupaten lainnya. Hal tersebut dikarenakan, Kabupaten Bangkalan hanya memiliki 117 petani garam yang tersebar di 5 Kecamatan dari 18 Kecamatan yang ada, dengan total luas lahan tambak garam sebesar 178 hektar. Kepala Dinas Keluatan dan Perikanan Bangkalan, melalui Kabid Budidaya Perikanan, Nur Laila menuturkan, 5 kecamatan penghasil garam rakyat tersebut terdiri dari Kamal (Desa Gili Barat) , Kwanyar (Desa Pesanggrahan), Klampis (Desa Moarah, Tolbuk, dan Kool), Sepuluh (Desa Maneron dan Labuhan) dan Tanjung Bumi (Desa Tlangoh dan Bumi Anyar). Yang paling banyak memproduksi garam adalah Kecamatan Sepuluh dan Tanjung Bumi (Dinas Kelautan dan Perikanan Bangkalan, 2015).

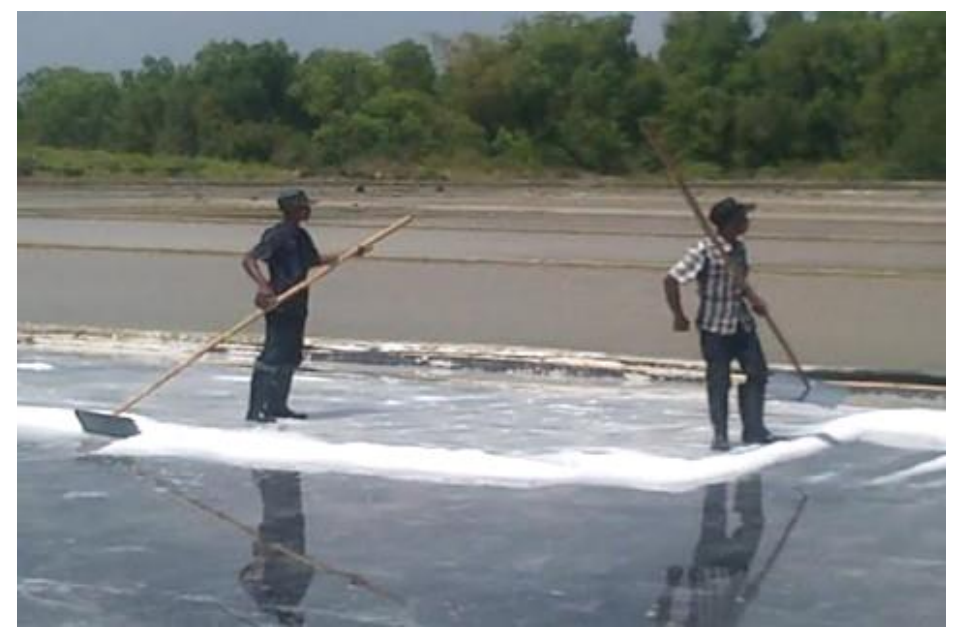

Foto Petani garam di Bangkalan

Kabupaten Sampang memiliki luas garam rakyat terluas di Madura yaitu mencapai 3.583,8 Ha dibandingkan dengan Kabupaten lain seperti Pamekasan sebesar 2.113,35 Ha dan Sumenep sebesar 1.944 Ha. Lahan pegaraman tersebut tersebar di 7 (tujuh) wilayah Kecamatan yaitu kecamatan Sampang, Pangarengan, Sreseh, Camplong, Torjun, Jrengik, dan Banyuates (Kementerian Kelautan dan Perikanan, 2013). 


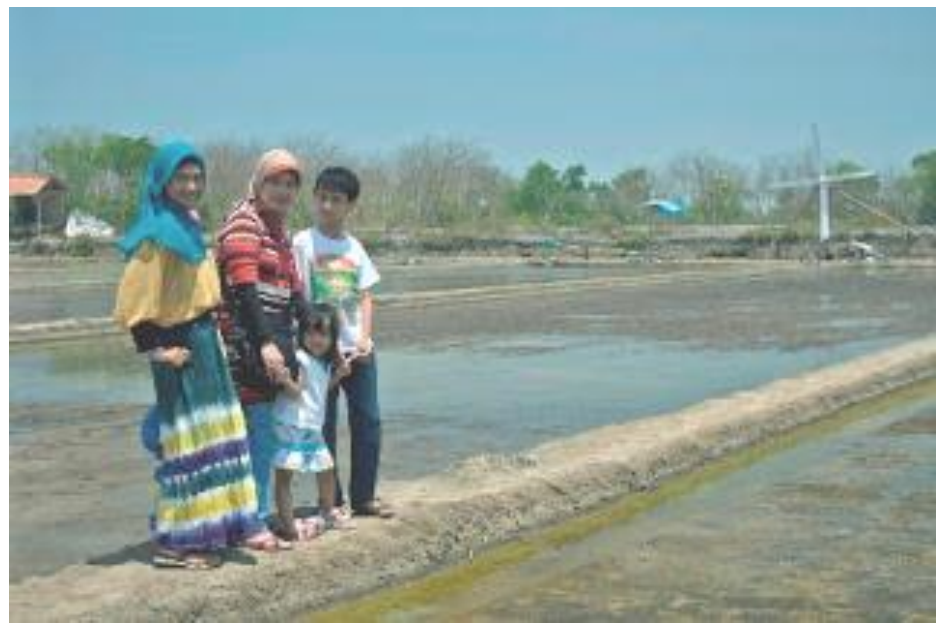

Foto pengunjung berpose di tengah tambak garam Sampang. Sumber:

niarningrum.com

Di Kabupaten Pamekasan jumlah total produksi garam hingga 30 Juli 2018 sebanyak 6.541,25 ton dari 15 desa penghasil garam yang tersebar di tiga kecamatan, yakni Kecamatan Galis, Pademawu dan Kecamatan Tlanakan dengan total luas areal tambak 913,5 hektare. (Dinas Kelautan dan Perikanan Pemkab Pamekasan, 2018). Selain menghasilkan garam, ladang-ladang tersebut juga mempunyai pesona wisata. Salah satunya adalah daerah Tanjung dan Jumiang. Hamparan tambak garam dan kilau puth garam menjadi daya tarik bagi wisatawan yang ingin mengetahui proses pembuatan garam sekaligus menikmati eksotisme panasnya tambak garam Madura.

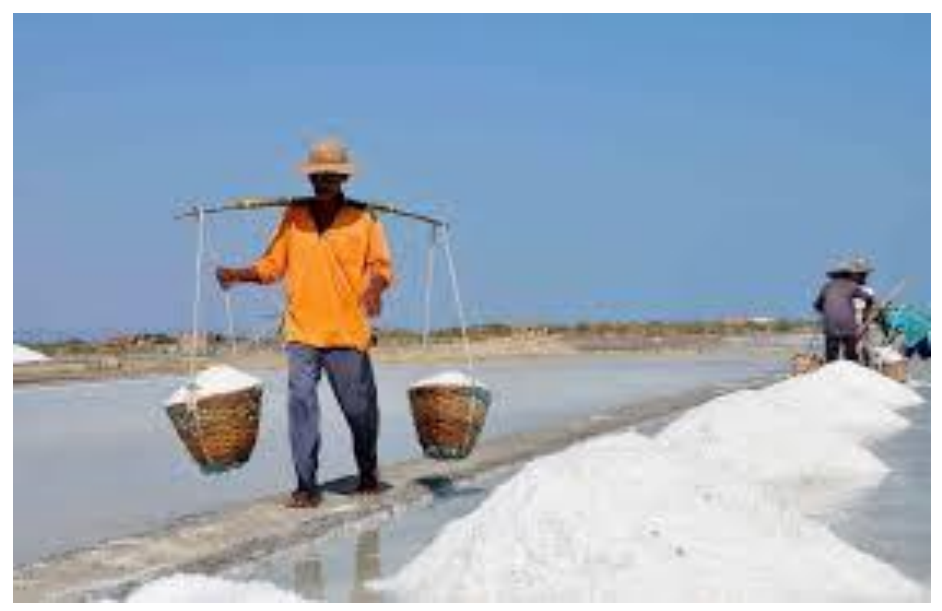

Foto sejumlah petambak garam sedang melakukan panen hasil produksi garamnya 
di dusun Mandala, Desa Bunder, Kecamatan Pademawu, Pamekasan

Sumenep yang disebut-sebut sebagai pusat garam Madura memiliki luas pertanian garam yang sangat luas, yakni mencapai 2.000 hektare. Sebagian lahan merupakan milik PT Garam yang pabriknya memang berlokasi di Kalianget dan sebagian lagi dikelola mandiri oleh rakyat. Sementara data di Dinas Perikanan Kabupaten Sumenep, lahan garam rakyat pada tahun ini seluas 2.068 hektar yang tersebar di sembilan kecamatan, yakni Kalianget, Gapura, Saronggi, Pragaan, Giligenting, Raas, Arjasa, Kangayan, dan Kecamatan Sapeken (Dinas Perikanan Kabupaten Sumenep, 2017).

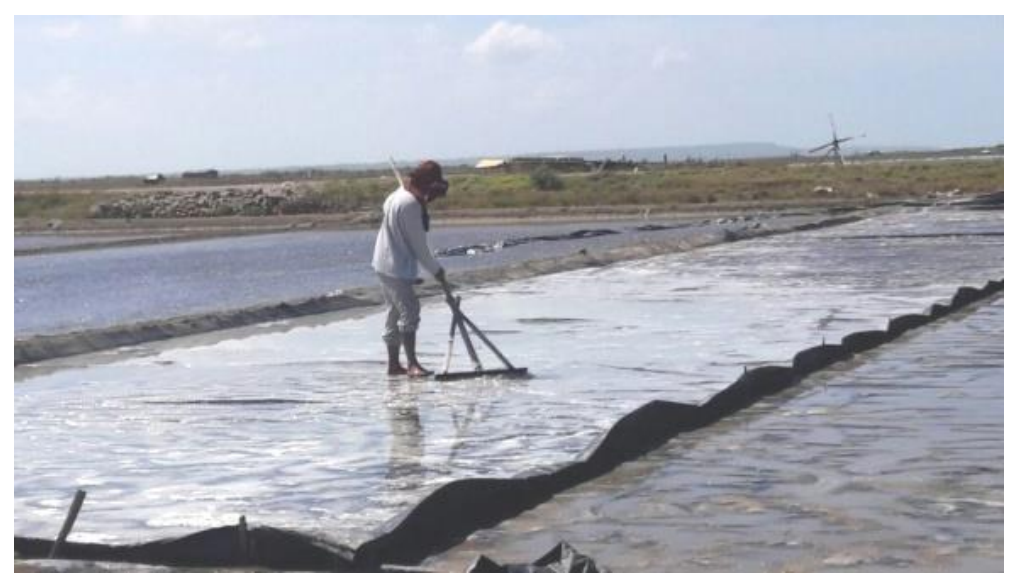

Foto Petani Garam Saat Menggarap Lahannya di Desa Pinggirpapas, Kecamatan Kalianget.

\section{B. Konsep Pengembangan Ekowisata Garam Melalui Pendekatan Triple Helix}

Dalam pengembangan ekowisata, sistem Triple Helix menjadi payung yang menghubungkan antara akademisi, bisnis dan pemerintah. Di mana ketiga helix tersebut merupakan aktor utama penggerak lahirnya kreativitas, ide, ilmu pengetahuan, dan teknologi yang vital bagi tumbuhnya ekowisata. Hubungan yang erat, saling menunjang, dan bersimbiosis mutualisme antara ke-3 aktor tersebut akan menentukan pengembangan ekowisata yang kokoh dan 
berkesinambungan.

Menurut Permendagri No. 33 Tahun 2009 tentang pedoman pengembangan ekowisata di daerah pada Pasal 1: Pengembangan ekowisata adalah kegiatan perencanaan, pemanfaatan, dan pengendalian ekowisata. Peran dari ketiga aktor triple helix yaitu akademisi, bisnis dan pemerintah dalam mengembangkan ekowisata garam dijabarkan berdasarkan kontribusinya terhadap kegiatan perencanaan, pemanfaatan dan pengendalian ekowisata.

\section{Perencanaan}

Peran Akademisi:

a. menghasilkan pengetahuan dan penelitian ilmiah untuk mendukung pelestarian budidaya garam.

b. mengembangkan dan menguatkan konsep ekowisata melalui pengamatan dan pengkajian potensi ekowisata garam

c. Mengembangkan model pembiayaan yang membuka akses seluas-luasnya untuk pendirian usaha oleh pelaku ekowisata, yaitu dengan mendorong peran serta aktif modal ventura, private equity (ekuitas swasta) dan business angel sebagai investor di bisnis ekowisata garam.

Peran pemerintah:

a. Melaksanakan perencanaan ekowisata sesuai dengan Permendagri No. 33 Tahun 2009 Pasal 6 yang dituangkan dalam Rencana Kerja Pemerintah Daerah (RKPD).

b. mengembangkan kemitraan dengan usaha mikro, kecil, dan koperasi setempat yang saling memerlukan, memperkuat, dan menguntungkan.

c. Merancang regulasi model pembiayaan yang dapat membuka akses seluasluasnya untuk pendirian usaha oleh pelaku ekowisata misalnya pembiayaan berupa pinjaman lunak, modal ventura, angel investor, koperasi, grameen, dan sebagainya.

Peran Bisnis: 
a. Berpartisipasi secara aktif dalam merancang pengembangan ekowisata yang dapat meningkatkan pemberdayaan ekonomi masyarakat lokal.

b. Mendukung serta mengadakan forum diskusi dengan lembaga pembiayaan sehingga para pelaku bisnis keuangan dapat lebih memahami pola bisnis ekowisata garam.

\section{Pemanfaatan}

Menurut Permendagri No. 33 Tahun 2009 Pasal 8: Pemanfaatan ekowisata mencakup: a. pengelolaan kawasan ekowisata; b. pemeliharaan kawasan ekowisata; c. pengamanan kawasan ekowisata; dan d. penggalian potensi kawasan ekowisata baru.

a. Pengelolaan kawasan ekowisata

Menurut Departemen Kebudayaan dan Pariwisata dan WWF-Indonesia (2009), salah satu prinsip ekowisata adalah prinsip partisipasi masyarakat yaitu ekonomi berbasis masyarakat. Homestay adalah sistem akomodasi yang sering dipakai dalam ekowisata. Homestay bisa mencakup berbagai jenis akomodasi dari penginapan sederhana yang dikelola secara langsung oleh keluarga sampai dengan menginap di rumah keluarga setempat. Homestay bukan hanya sebuah pilihan akomodasi yang tidak memerlukan modal yang tinggi, dengan sistem homestay pemilik rumah dapat merasakan secara langsung manfaat ekonomi dari kunjungan turis, dan distribusi manfaat di masyarakat lebih terjamin.

- Peran pemerintah: mendorong adanya prosedur sertifikasi pemandu sesuai dengan kondisi lokasi wisata.

- Peran akademisi : mendorong ketersediaan homestay melalui mentoring dan melatih masyarakat lokal melalui pemberian pelatihan mulai dari bagaimana menyambut dan melayani tamu; menyajikan makanan; pengaturan homestay, melatih percakapan bahasa Inggris.

- Peran akademisi dan pemerintah: 1) mendorong adanya regulasi yang mengatur standar kelayakan homestay sesuai dengan kondisi lokasi wisata; 
2) mendorong peningkatan pengetahuan dan keterampilan serta perilaku bagi para pelaku ekowisata terutama masyarakat

- Peran bisnis: 1) Mengembangkan sebuah unit-unit ekonomi (BUMDESBadan Usaha Milik Desa) dan Koperasi untuk mendukung aktivitas dan kebutuhan para wisatawan, mulai dari unit usaha makanan, souvenir, MCK, transportasi, penginapan, parkir hingga pemandu wisata; 2) Mengembangkan paket-paket wisata yang mengedepankan budaya, seni dan tradisi lokal. Misalnya kegiatan sehari-hari termasuk panen garam dapat dimasukkan ke dalam atraksi lokal untuk memperkenalkan wisatawan pada cara hidup masyarakat dan mengajak mereka menghargai pengetahuan dan kearifan lokal.

b. Pemeliharaan kawasan ekowisata

Kegiatan ekowisata mendorong masyarakat mendukung dan mengembangkan upaya konservasi. Hal ini sesuai dengan Permendagri No. 33 Tahun 2009 Pasal 3 tentang prinsip pengembangan ekowisata khususnya edukasi, yaitu mengandung unsur pendidikan untuk mengubah persepsi seseorang agar memiliki kepedulian, tanggung jawab, dan komitmen terhadap pelestarian lingkungan dan budaya.

- Peran akademisi: membuka akses kepustakaan dan informasi bagi masyarakat luas yang ingin mengetahui tentang industri garam di Madura sehingga diharapkan akan menimbulkan minat untuk melakukan ekowisata garam. Menghidupkan forum-forum komunitas diskusi di lingkungan kampus dan masyarakat yang berorientasi pada pengembangan ekowisata garam.; memberikan sosialisasi sadar wisata kepada masyarakat di desadesa penghasil garam akan pentingnya pelestarian budidaya garam

- Peran bisnis: berperan aktif dalam upaya pengembangan prasarana dan program pemberdayaan masyarakat. Peran ini dilakukan oleh masyarakat lokal sebagai pengelola ekowisata dengan memberikan edukasi kepada wisatawan akan pentingnya pelestarian budidaya garam; Mengembangkan skema di mana tamu secara sukarela terlibat dalam kegiatan konservasi 
dan pengelolaan kawasan ekowisata selama kunjungannya (stay \& volunteer).

- Peran pemerintah: memberikan insentif untuk pelestarian budidaya garam.

c. Pengamanan kawasan ekowisata

- Peran akademisi: menghasilkan pengetahuan dan penelitian ilmiah untuk mendukung pelestarian budidaya garam khususnya di bidang inovasi teknologi untuk memperbaiki sistem produksi garam agar lebih produktif.

- Peran bisnis: Menurut Undang-Undang Nomor 10 tahun 2009 tentang Kepariwisataan Pasal 26, setiap pengusaha pariwisata berkewajiban: a. memberikan kenyamanan, keramahan, perlindungan keamanan, dan keselamatan wisatawan; b. turut serta mencegah segala bentuk perbuatan yang melanggar kesusilaan dan kegiatan yang melanggar hukum di lingkungan tempat usahanya; c. memelihara lingkungan yang sehat, bersih, dan asri; d. memelihara kelestarian lingkungan alam dan budaya.

- Peran pemerintah: menciptakan iklim yang kondusif untuk perkembangan usaha pariwisata yang meliputi terbukanya kesempatan yang sama dalam berusaha, memfasilitasi, dan memberikan kepastian hukum (UndangUndang Nomor 10 tahun 2009 tentang Kepariwisataan Pasal 23 ayat 1).

\section{Pengendalian}

Peran ketiga aktor triple helix dalam pengendalian ekowisata:

a. Peran pemerintah: 1) Pemberian izin pengembangan ekowisata dan menerapkan standar usaha dan standar kompetensi sesuai dengan ketentuan peraturan perundang-undangan (Undang-Undang Nomor 10 tahun 2009 tentang Kepariwisataan Pasal 23 ayat 1);2) Penertiban atas penyalahgunaan izin pengembangan ekowisata; 3) Memberikan bantuan advokasi/hukum bagi penanganan dan penyelesaian masalah atau konflik yang timbul dalam penyelenggaraan ekowisata

b. Peran akademisi: memberikan konsultasi ahli bagi penanganan dan 
penyelesaian masalah atau konflik yang timbul dalam penyelenggaraan ekowisata.

c. Peran akademisi, bisnis dan pemerintah: pemantauan pengembangan ekowisata.

Menurut Departemen Kebudayaan dan Pariwisata dan WWF-Indonesia Tahun 2009, ada dua aspek yang sangat terkait dan perlu dibahas secara bersamaan jika ingin mengembangkan ekowisata berbasis masyarakat sebagai satu usaha yang berhasil. Usaha harus layak secara ekonomi, menghasilkan pendapatan yang signifikan untuk masyarakat setempat, dan dikelola secara profesional. Kemudian, usaha tersebut perlu adil, bermanfaat buat masyarakat lokal sebagai mitra utama, dan pendidikan dan pelatihan.

\section{KESIMPULAN DAN SARAN}

\section{Kesimpulan}

a. Potensi budidaya garam di empat kabupaten di Madura yaitu Bangkalan, Sampang, Pamekasan dan Sumenep dapat dijadikan peluang untuk mengembangkan wisata yang menarik melalui konsep ekowisata garam. Hal ini karena lahan pegaraman Madura dapat memenuhi lima prinsip dasar pengembangan ekowisata di Indonesia yaitu prinsip pelestarian, pendidikan, pariwisata, ekonomi, dan partisipasi masyarakat setempat.

b. Dalam konsep pengembangan ekowisata, kegiatan yang dilakukan adalah mulai dari perencanaan, pemanfaatan dan pengendalian.

c. Ekowisata garam memerlukan kolaborasi dari pihak akademisi, bisnis yang diwakili oleh kelompok petani garam, dan pemerintah. Ketiga aktor ini yang dinamakan dengan triple helix memiliki peran yang berbeda-beda dalam rangka untuk mengembangkan ekowisata garam.

\section{Saran}

a. Pengembangan ekowisata garam di Pulau Madura semaksimal mungkin harus dapat melibatkan pihak akademisi, masyarakat dan pemerintah daerah 
secara optimal dalam setiap proses-proses di dalamnya. Hal ini dilakukan guna memberikan ruang yang luas bagi masyarakat setempat untuk menikmati keuntungan secara ekonomi dari pengembangan ekowisata di wilayah ini.

b. Terciptanya serta terjalinnya komunikasi yang intens antara pemerintah daerah, Perguruan tinggi di wilayah Madura, serta masyarakat lokal, sehingga semua hal yang terkait untuk pengembangan usaha dapat dicapai.

c. Dibentuk suatu forum komunitas yang melibatkan ketiga fihak. Forum ini selain berfungsi sebagai sarana komunikasi, juga sebagai sarana untuk pembinaan dan pelatihan yang bersifat kontinyu.

\section{DAFTAR PUSTAKA}

Black, R. 1999. Ecotourism and education. Available at http//www.findarticles.com

Departemen Kebudayaan dan Pariwisata dan WWF-Indonesia. 2009. Prinsip dan Kriteria Ekowisata Berbasis Masyarakat

Etzkowitz, H. 2008. The Triple Helix: University-Industry-Government Innovation in Action. Routledge, London and New York, 15. https://doi.org/10.4324/9780203929605

Hapsari, Nurul Retno and Sitta Nurhajijah. 2017. The Role of Triple Helix in Ecotourism Development at Cibuntu Village of Kuningan District West Java. The 9th International Graduate Students and Scholars' Conference in Indonesia (IGSSCI)

Page, S., 2009. Tourism Management. 3rd ed. Oxford: Btterworth-Heinemann. Permendagri Nomor 33. 2009. Pedoman Pengembangan Ekowisata di Daerah Sastrayuda, Gumelar S. 2010. "Hand Out Mata Kuliah Concept Resort And

Leisure, Strategi Pengembangan dan Pengelolaan Resort and Leisure".

Undang-Undang Republik Indonesia.No. 10 Tahun 2009. Tentang Kepariwisataan Sumber Media Online:

http://surabaya.tribunnews.com/2018/02/16/ketika-garam-tak-asin-lagi-tergerusmoderinasi-hingga-garam-impor?page $=3$. https://jatim.antaranews.com/berita/260905/lahan-tambak-garam-sampang-terus$\underline{\text { menyusut }}$ https://travel.kompas.com/read/2017/11/01/193500927/ini-tantanganpengembangan-pariwisata-tahun-2018 